\title{
Acidic culture medium enhances secretion of myoglobin and GDF-15 in MCF-7 breast cancer cells- multiplex assay data
}

Catherine Mary Worsley ( $\sim$ u05116602@up.ac.za )

University of Pretoria https://orcid.org/0000-0002-0710-4828

Rob B Veale

University of the Witwatersrand

Elizabeth S Mayne

University of Cape Town

\section{Research Article}

Keywords: Breast cancer, cytokines, chemokines, growth factors, myoglobin, GDF-15, low pH

Posted Date: March 2nd, 2022

DOI: https://doi.org/10.21203/rs.3.rs-1411459/v1

License: (c) (i) This work is licensed under a Creative Commons Attribution 4.0 International License.

Read Full License 


\section{Abstract}

Metastatic breast cancer is one of the leading causes of cancer mortality worldwide. While many therapeutic strategies try to control and combat this disease, a better understanding of cellular communication within the acidic tumour microenvironment is needed to improve treatment success. Here we characterized the secretory profile of MCF-7 breast cancer cells in medium of physiological $\mathrm{pH}$, and compared it to those cells treated with medium of 6.5 and 3.2. MCF-7 cells secreted IP-10, VEGF, EGF, FGF, G-CSF, GDF-15, and myoglobin at baseline. When treated with acidic medium, MCF-7 cells downregulated secretion of many of these factors, although myoglobin and GDF-15 were significantly increased at $\mathrm{pH}$ $6.5(1 \mathrm{hr})(\mathrm{p}<0.0001)$. This may provide a survival advantage to the tumour cells at slightly acidic $\mathrm{pH}$. Further studies investigating the effects of acidosis on breast carcinoma cells are needed to understand both their autocrine and paracrine signaling functions in the tumour microenvironment.

\section{Introduction}

The tumour microenvironment (TME) is typically acidic owing to high levels of glycolysis, and secretion of $\mathrm{H}+$ ions and lactate from tumour cells [1]. Reciprocal signaling occurs between tumour cells and their microenvironment that impact on cell growth and proliferation, invasion, metastasis, and evasion of the immune system [1]. Acidosis is involved in invasion and metastatic progression of breast cancer [2]. Little is known however, about the exact impact of the acidosis on the cells themselves, or on their secretory profile.

Intercellular signaling is important for controlling cellular processes in both normal and cancerous tissues. Tumour cells secrete factors that recruit other cells to the TME to assist with extracellular matrix (ECM) remodeling, angiogenesis, and tumour cell motility. Several complex cytokine, chemokine, and growth factor networks are associated with tumorigenesis. In the TME, these secreted proteins can either effect tumour growth and proliferation through autocrine or paracrine signaling, can modify the activity of surrounding stromal cells, or can influence the activity of immune cells[3]. They affect many downstream signaling pathways, and some have been proposed as potential therapeutic targets.

Breast cancer cells secrete many factors into the TME. MCF-7, a commonly studied breast cancer cell line, is both estrogen receptor (ER) and progesterone receptor (PR) positive [4], which makes it a useful model for studying anti-hormone therapy. It is only weakly metastatic under normal cell culture conditions, with high aneuploidy, and with elevated levels of genetic instability [4]. The epidermal growth factor (EGF) receptor (EGFR) and human epidermal growth factor receptor-2 (HER2) control the growth of the MCF-7 cell line, and the autocrine vascular endothelial growth factor (VEGF) feedback loop that promotes angiogenesis [4]. Other growth factors and signaling molecules are known to play a role in promoting tumourigenesis in other cancers, including in breast cancer. We have highlighted the analytes of interest assayed in this study, and have briefly summarized what is currently known about their pro- or antitumorigenic roles in breast cancer specifically (Table 1 ). 
While a number of reports explore the influence of cytokines, chemokines, and growth factors on MCF-7 cells, few studies have investigated which of these factors are secreted by the tumour cells themselves. In addition, the impact of the acidic TME on proteins secreted by MCF-7 has not been investigated. This study aims to characterized the secretory profile of MCF-7 cells, and study the effects of extracellular acidity on secretion of these proteins.

\section{Methods}

\subsection{Cell lines}

The breast carcinoma cell line MCF-7 was cultured in Dulbecco's Modified Eagle's Medium (DMEM)/Hams F12 (3:1) supplemented with $10 \%$ fetal calf serum (FCS) and $2 \%$ penicillin/streptomycin. Cells were maintained at $37^{\circ} \mathrm{C}$ with humidity, with $5 \% \mathrm{CO}_{2}$ in air, and were passaged when reaching $\sim 80 \%$ confluency.

\subsection{Experimental conditions}

Cells were counted, and 150000 cells were seeded into $6 \mathrm{~cm}$ culture dishes, and were treated as described previously [5]. Briefly, cells were treated with medium of $\mathrm{pH} 6.5$ and 3.2 for 15 minutes and 1 hour. Acidic medium was removed, cells were washed with phosphate buffered saline (PBS), and were incubated for 24 hours in serum-free medium. The conditioned medium was removed and stored at $-20^{\circ} \mathrm{C}$. An untreated control was included to measure baseline secretory protein levels.

\subsection{Luminex assay}

Protein concentrations in conditioned culture media were measured using the following kits: Human Cytokine 10-Plex Panel (Cat \#LHC001, Invitrogen), Human Chemokine 10-Plex Panel (cat \#LHC6001, Invitrogen), Human Growth Factor 4-Plex Panel (cat \# LHC0004, Invitrogen), SDF-1 alpha Human ProcartaPlex $^{\text {TM }}$ Simplex Kit (EPX01A-12138-901, Invitrogen), and Human Cardiovascular Disease (CVD) Magnetic Bead Panel (HCVD2MAG-67K, Merck Millipore) following manufacturer's instructions. Standards and samples were assayed in duplicate on the Luminex Bio-Plex 200 analyzer (Bio-Rad) using Bio-Plex Manager v 5.0 software.

\subsection{Statistical analyses}

Sample concentrations were determined from standard curves for each analyte. Descriptive statistics including mean concentrations and standard deviations were determined for all samples. One- and twoway ANOVAs were performed, followed by post-hoc Dunnett's tests for multiple comparisons. All analyses were performed using GraphPad Prism for Windows version 9.3.1 (California, USA). 


\section{Data}

\subsection{Baseline secretion of cytokines, chemokines, and growth factors}

To evaluate the baseline levels of cytokine, chemokine, and growth factor secretion we incubated MCF-7 cells in serum-free medium for 24 hours. We measured the concentration of 32 analytes (as listed in Table 1) secreted into the medium, of which only 7 were detectable. These included interferon-y inducible protein-10 (IP-10), VEGF, EGF, fibroblast growth factor (FGF), and myoglobin, which were expressed at moderate levels, with higher levels of expression of growth-differentiation factor-15 (GDF-15) and granulocyte colony-stimulating factor (G-CSF). Descriptive statistics including mean and standard deviation of replicates are reported (Supplementary data Table S1).

\subsection{Brief acid exposure affects levels of protein secreted by MCF-7 cells}

Protein concentrations were determined for each analyte in the different acid medium treatments. Twoway ANOVA analysis comparing the combined mean protein concentrations of all analytes between the different acid treatment groups showed the effect of acidic medium treatment as extremely significant, $(p<0.0001)$. Post-hoc Dunnett's test showed that comparisons between the untreated control and each acidic treatment were also highly significant (Table 2). For most of the acidic medium treatments, the combined mean protein concentration was significantly lower than the untreated control $(p<0.0001)$, however, it was significantly higher in cells treated with $\mathrm{pH} 6.5$ for $1 \mathrm{hr}$ compared to the untreated control (mean 675.3 vs. $294.0 \mathrm{pg} / \mathrm{ml}$ respectively, $\mathrm{p}<0.0001$ ).

One-way ANOVA analysis compared the mean concentrations of each analyte between the different acidic medium treatments (Table 3). Significance was determined as $p<0.05$. With the exception of G-CSF and IP-10, significant differences in the mean concentrations were observed between different $\mathrm{pH}$ treatments for the other analytes, with GDF-15 and myoglobin being the most significant $(p<0.0001)$. Post-hoc Dunnett's comparison tests revealed significant differences in a number of different analytes with different acidic medium treatments compared to the untreated control. Again, GDF-15 and myoglobin were highly significant with all acidic treatments compared to the untreated control (Table 3). With these two analytes, in most of the acidic medium treatments, the mean protein concentration was significantly lower than the untreated control $(p<0.0001)$. The mean protein concentration was however significantly higher in cells treated with $\mathrm{pH} 6.5$ for $1 \mathrm{hr}$ compared to the untreated control (GDF-15: mean 3824 vs. 1379 pg/ml, $p<0.0001$; myoglobin: mean 462.5 vs. 171.8 pg/ml, $p<0.0001$ ).

\section{Discussion}

In the study, we aimed to assess the effect of an acidic microenvironment of the secretion of proteins by the human MCF-7 breast cancer cell line. At baseline, this cell line secreted the chemokine IP-10, growth factors GDF-15, VEGF, EGF, G-CSF, FGF, as well as myoglobin. There was no secretion of a number of 
other pro- and anti-inflammatory cytokines, as well as chemokines, which is in keeping with other studies $[6,7]$.

When treating the cells with acidic medium of $\mathrm{pH} 3.2$, there was a general reduction in protein secretion, possibly indicating that highly acidic $\mathrm{pH}$ compromises cellular integrity and function. Of note, G-CSF concentration was not significantly affected by acidic medium. This may be advantageous, as G-CSF acts in an autocrine loop to enhance EMT, migration, and invasion of breast cancer cells through activation of Stat3 [8], and also impairs the activity of neutrophils, macrophages, and fibroblasts [8]. EGF, and FGF expression were also not significantly affected, which may offer some tumour cell protection in an acidic microenvironment, although VEGF expression was significantly reduced $(p<0.01)$, which may impact tumour angiogenesis under low pH conditions.

In contrast, tumour cell function was largely preserved under mildly acidic conditions with the expression of myoglobin and GDF-15, which was significantly elevated in cells treated at $\mathrm{pH} 6.5$ for $1 \mathrm{hr}$. Myoglobin is a key effector of oxygen storage and distribution, and its expression is induced in epithelial tumours in response to mitogenic stimuli, oxidative stress, and hypoxia [9]. In our study, myoglobin was expressed at a moderate level in the baseline samples, and although expression decreased at most treatment points, it was significantly elevated when treated with medium of pH 6.5 for $1 \mathrm{hr} .(\mathrm{p}<0.0001)$. Myoglobin may assist to scavenge nitric oxide (NO) and reactive oxygen species (ROS), as well as binding oxygen to provide an adaptive advantage to MCF-7 tumour cells. GDF-15 is a pleomorphic cytokine. It can promote tumour growth arrest and apoptosis (including in MCF-7 cell lines), but may also promote tumour proliferation in malignant glioma cells [10]. More importantly, GDF-15 has significant immunomodulatory functions including blocking lymphocyte recruitment to the TME, dendritic cell (DC) maturation, and antigen presentation, promoting trafficking of tumour-associated macrophages (TAMs) to the TME, and preventing tumour destruction by natural killer cells [10-12].

In conclusion, we successfully identified a number of analytes that are secreted by MCF-7 cells. Levels of specific analytes were significantly increased when tumour cells were treated with acidic media of pH 6.5. These may provide a selective advantage, ensuring survival of tumour cells in the acidic TME, as well as preventing tumour cell destruction by the immune system. Thus, the acidic tumour microenvironment promotes the evolution of tumour cells, and identifying and targeting these biomarkers could be of prognostic and therapeutic use.

\section{Limitations}

Our data reflect changes in protein secretion using decreasing $\mathrm{pH}$ in culture medium. It is possible that this may not represent the changes that happen in vivo. It would be of interest to compare these results to other cell lines. MCF-7 is one of the least aggressive breast cancer cells lines, and it would be interesting to compare secretory profiles of more aggressive cells lines under similar conditions. In addition, cells treated with medium of pH 6.5 for 1 hr expressed significantly higher levels of myoglobin and GDF-15. 
Future studies should look at the effects of this $\mathrm{pH}$ over a longer treatment period to see if there are any other significant observations that can be made.

\section{Abbreviations}

DC - dendritic cell; DMEM - Dulbecco's Modified Eagle's Medium; ECM - extracellular matrix; EGF epidermal growth factor; EGFR - epidermal growth factor receptor; EMT - epithelial-mesenchymal transition; ER - estrogen receptor; FCS - fetal calf serum; FGF - fibroblast growth factor; G-CSF granulocyte colony-stimulating factor; GDF-15 - growth/differentiation protein-15; GM-CSF - granulocyte macrophage colony-stimulating factor; GRO- $a$ - Growth regulated oncogene- $a$; HER2 - human epidermal growth factor receptor-2; IFN- $\gamma$ - interferon- $\gamma$; IL-1 $\beta$ - interleukin-1 $\beta$; IL-2 - interleukin-2; IL-4 - interleukin4; IL-6 - interleukin-6; IL-8 - interleukin-8; IL-10 - interleukin-10; IP-10 - interferon- $\gamma$ inducible protein-10; MCP-1 - monocyte chemoattractant protein-1; MCP-2 - monocyte chemoattractant protein-2; MCP-3 monocyte chemoattractant protein-3; MIG - Monokine induced gamma interferon; MIP-1a - Macrophage inflammatory protein -1a; MIP-1 $\beta$ - Macrophage inflammatory protein - $1 \beta$; MPO - myeloperoxidase; NK natural killer; NO - nitric oxide; PR - progesterone receptor; ROS - reactive oxygen species; SDF-1 -

Stromal cell-derived factor 1; sICAM-1 - soluble intercellular cell adhesion molecule-1; sVCAM-1 - soluble vascular cell adhesion molecule-1; TAM - tumour-associated macrophage; TME - tumour microenvironment; TNF- $a$ - tumour necrosis factor-a; Treg - regulatory T cell; VEGF - vascular endothelial growth factor; VEGFR1 - vascular endothelial growth factor receptor-1

\section{Declarations}

Use of this commercially available cell line was approved by the Human Research Ethics Committee of the University of the Witwatersrand, South Africa (approval number M120205).

Consent for publication: Not applicable

Availability of data and materials (links to datasets): All data generated or analyzed during this study are included in this published article.

Competing interests: The authors declare that they have no competing interests

Funding: This research was funded by the National Research Foundation (NRF) Thuthuka program (www.nrf.ac.za), grant number TTK20110727000022309 awarded to CMW.

Authors' contributions: CMW (study design, laboratory work, statistical analysis, writing of article), RBV (review of article), ESM (project supervision, significant article review)

Acknowledgements: Not applicable

\section{References}


1. Worsley C, Veale R, Mayne E. The acidic tumour microenvironment: Manipulating the immune response to elicit escape. Hum Immunol. 2022.

2. Gupta SC, Singh R, Asters M, Liu J, Zhang X, et al. Regulation of breast tumorigenesis through acid sensors. Oncogene. 2016;35(31):4102-11.

3. Andreola G, Rivoltini L, Castelli C, Huber V, Perego P, et al. Induction of lymphocyte apoptosis by tumor cell secretion of FasL-bearing microvesicles. J Exp Med. 2002;195(10):1303-16.

4. Comsa S, Cimpean A, Raica M. The story of MCF-7 breast cancer cell line: 40 years of experience in research. Anticancer Res. 2015;35:3147-54.

5. Worsley C, Veale R, Mayne E. Inducing apoptosis using chemical treatment and acidic $\mathrm{pH}$, and detecting it using the Annexin V flow cytometric assay. PLoS One. 2022.

6. Ortiz-Montero P, Londono-Vallejo A, Vernot JP. Senescence-associated IL-6 and IL-8 cytokines induce a self- and cross-reinforced senescence/inflammatory milieu strengthening tumorigenic capabilities in the MCF-7 breast cancer cell line. Cell Commun Signal. 2017;15(1):17.

7. Chen K, Satlof L, Stoffels G, Kothapalli U, Ziluck N, et al. Cytokine secretion in breast cancer cells MILLIPLEX assay data. Data Brief. 2020;28:104798.

8. Liu L, Wu Y, Zhang C, Zhou C, Li Y, et al. Cancer-associated adipocyte-derived G-CSF promotes breast cancer malignancy via Stat3 signaling. J Mol Cell Biol. 2020;12(9):723-37.

9. Flonta SE, Arena S, Pisacane A, Michieli P, Bardelli A. Expression and functional regulation of myoglobin in epithelial cancers. Am J Pathol. 2009;175(1):201-6.

10. Corre J, Hebraud B, Bourin P. Concise review: growth differentiation factor 15 in pathology: a clinical role? Stem Cells Transl Med. 2013;2(12):946-52.

11. Lodi RS, Yu B, Xia L, Liu F. Roles and Regulation of Growth differentiation factor-15 in the Immune and tumor microenvironment. Hum Immunol. 2021;82(12):937-44.

12. Zhou Z, Li W, Song Y, Wang L, Zhang K, et al. Growth differentiation factor- 15 suppresses maturation and function of dendritic cells and inhibits tumor-specific immune response. PLOS ONE. 2013;8(11):e78618.

13. Rebe C, Ghiringhelli F. Interleukin-1beta and Cancer. Cancers (Basel). 2020; 12(7).

14. Chaurasiya S, Hew P, Crosley P, Sharon D, Potts K, et al. Breast cancer gene therapy using an adenovirus encoding human IL-2 under control of mammaglobin promoter/enhancer sequences. Cancer Gene Ther. 2016;23(6):178-87.

15. Little AC, Pathanjeli P, Wu Z, Bao L, Goo LE, et al. IL-4/IL-13 Stimulated Macrophages Enhance Breast Cancer Invasion Via Rho-GTPase Regulation of Synergistic VEGF/CCL-18 Signaling. Front Oncol. 2019;9:456.

16. Al-Khalaf H, Al-Harbi B, Al-Sayed A, Arafah M, Tulbah A, et al. Interleukin-8 Activates Breast CancerAssociated Adipocytes and Promotes Their Angiogenesis- and Tumorigenesis-Promoting Effects. Mol Cell Biol. 2019;39(2):e00332-18. 
17. Chang CM, Lam HYP, Hsu HJ, Jiang SJ. Interleukin-10: A double-edged sword in breast cancer. Tzu Chi Med J. 2021;33(3):203-11.

18. Heimes AS, Hartner F, Almstedt K, Krajnak S, Lebrecht A, et al. Prognostic Significance of Interferongamma and Its Signaling Pathway in Early Breast Cancer Depends on the Molecular Subtypes. Int J Mol Sci. 2020; 21(19).

19. Cruceriu D, Baldasici O, Balacescu O, Berindan-Neagoe I. The dual role of tumor necrosis factor-alpha (TNF-alpha) in breast cancer: molecular insights and therapeutic approaches. Cell Oncol (Dordr). 2020;43(1):1-18.

20. Kochumon S, Al-Sayyar A, Jacob T, Hasan A, Al-Mulla F, et al. TNF-alpha Increases IP-10 Expression in MCF-7 Breast Cancer Cells via Activation of the JNK/c-Jun Pathways. Biomolecules. 2021; 11(9).

21. Tripathi C, Tewari B, Kanchan R, Baghei K, Nautiyal N, et al. Macrophages are recruited to hypoxic tumor areas and acquire a Pro-Angiogenic M2-Polarized phenotype via hypoxic cancer cell derived cytokines Oncostatin M and Eotaxin. Oncotarget. 2014;5:5350-68.

22. Gallo M, Frezzetti D, Chicchinelli CR, Barbieri N. A, et al. RANTES and IL-6 cooperate in inducing a more aggressive phenotype in breast cancer cells. Oncotarget. 2018;9(25):17543-53.

23. Dutta P, Sarkissyan M, Paico K, Wu Y, Vadgama JV. MCP-1 is overexpressed in triple-negative breast cancers and drives cancer invasiveness and metastasis. Breast Cancer Res Treat. 2018;170(3):47786.

24. He J, Li CF, Lee HJ, Shin DH, Chern YJ, et al. MIG-6 is essential for promoting glucose metabolic reprogramming and tumor growth in triple-negative breast cancer. EMBO Rep. 2021;22(5):e50781.

25. Mego M, Cholujova D, Minarik G, Sedlackova T, Gronesova P, et al. CXCR4-SDF-1 interaction potentially mediates trafficking of circulating tumor cells in primary breast cancer. BMC Cancer. 2016;16:127.

26. Santolla MF, Maggiolini M. The FGF/FGFR System in Breast Cancer: Oncogenic Features and Therapeutic Perspectives. Cancers (Basel). 2020; 12(10).

27. Sasahara A, Tominaga K, Nishimura T, Yano M, Kiyokawa E, et al. An autocrine/paracrine circuit of growth differentiation factor (GDF) 15 has a role for maintenance of breast cancer stem-like cells. Oncotarget. 2017;8(15):24869-81.

28. Hu C, Yang K, Li M, Huang W, Zhang F, et al. Lipocalin 2: a potential therapeutic target for breast cancer metastasis. Onco Targets Ther. 2018;11:8099-106.

29. Zeindler J, Angehrn F, Droeser R, Daster S, Piscuoglio S, et al. Infiltration by myeloperoxidase-positive neutrophils is an independent prognostic factor in breast cancer. Breast Cancer Res Treat. 2019;177(3):581-9.

30. Quinting T, Heymann AK, Bicker A, Nauth T, Bernardini A, et al. Myoglobin Protects Breast Cancer Cells Due to Its ROS and NO Scavenging Properties. Front Endocrinol (Lausanne). 2021;12:732190.

31. Thielemann A, Baszczuk A, Kopczynski Z, Nowak A, Grodecka-Gazdecka S. The clinical usefulness of assessing the concentration of cell adhesion molecules SVCAM-1 and SICAM-1 in the serum of women with primary breast cancer. Contemp Oncol (Pozn). 2014;18(4):252-9. 
32. Gomes FG, Sandim V, Almeida VH, Rondon AMR, Succar BB, et al. Breast-cancer extracellular vesicles induce platelet activation and aggregation by tissue factor-independent and -dependent mechanisms. Thromb Res. 2017;159:24-32.

\section{Tables}

Table 1. Analytes of interest and their roles in breast cancer 


\begin{tabular}{|c|c|c|c|}
\hline Analyte & Reported activity in breast cancer & $\begin{array}{l}\text { Pro- or anti- } \\
\text { tumorigenic }\end{array}$ & Reference \\
\hline Interleukin-1 $\beta$ (IL-1 $\beta)$ & $\begin{array}{l}\text { Upregulated expression leads to } \\
\text { upregulation of IL-6 }\end{array}$ & Pro & [13] \\
\hline Interleukin-2 (IL-2) & $\begin{array}{l}\text { Induces T cell responses to destroy tumour } \\
\text { cells }\end{array}$ & Anti & [14] \\
\hline Interleukin-4 (IL-4) & $\begin{array}{l}\text { Stimulates macrophages to increase } \\
\text { breast cancer cell invasion }\end{array}$ & Pro & [15] \\
\hline Interleukin-6 (IL-6) & $\begin{array}{l}\text { Increased IL- } 6 \text { leads to an increase in } \\
\text { luminal-type breast cancer }\end{array}$ & Pro & [13] \\
\hline Interleukin-8 (IL-8) & $\begin{array}{l}\text { Enhances angiogenic effects of breast } \\
\text { adipocytes }\end{array}$ & Pro & [16] \\
\hline Interleukin-10 (IL-10) & $\begin{array}{l}\text { Released by tumour-associated } \\
\text { macrophages (TAMs) and regulatory T } \\
\text { cells (Tregs), promoting tumourigenesis }\end{array}$ & Pro & [17] \\
\hline $\begin{array}{l}\text { Granulocyte macrophage } \\
\text { colony-stimulating factor } \\
\text { (GM-CSF) }\end{array}$ & Induces cytotoxic immune cell activity & Anti & [14] \\
\hline Interferon- $\gamma$ (IFN- $\gamma)$ & Enhances CD8 cytotoxic activity & Anti & [18] \\
\hline $\begin{array}{l}\text { Tumour necrosis factor- } \\
\text { a (TNF-a) }\end{array}$ & $\begin{array}{l}\text { Involved in driving epithelial-mesenchymal } \\
\text { transition (EMT) and metastasis }\end{array}$ & Pro & [19] \\
\hline $\begin{array}{l}\text { Interferon-y inducible } \\
\text { protein-10 (IP-10) }\end{array}$ & $\begin{array}{l}\text { Promotes recruitment of } \mathrm{T} \text { cells to tumour } \\
\text { site }\end{array}$ & Anti & [20] \\
\hline Eotaxin & $\begin{array}{l}\text { Attracts M2 macrophages to hypoxic areas } \\
\text { of tumour }\end{array}$ & Pro & [21] \\
\hline Rantes & $\begin{array}{l}\text { Co-operates with IL- } 6 \text { to induce aggressive } \\
\text { metastatic phenotypes }\end{array}$ & Pro & [22] \\
\hline $\begin{array}{l}\text { Monocyte } \\
\text { chemoattractant protein } 1 \\
\text { (MCP-1) }\end{array}$ & Drives invasion and metastasis & Pro & [23] \\
\hline $\begin{array}{l}\text { Monocyte } \\
\text { chemoattractant protein } 2 \\
\text { (MCP-2) }\end{array}$ & Unknown significance in breast & Unknown & \\
\hline $\begin{array}{l}\text { Monocyte } \\
\text { chemoattractant protein } 3 \\
\text { (MCP-3) }\end{array}$ & Unknown significance in breast & Unknown & \\
\hline $\begin{array}{l}\text { Growth regulated } \\
\text { oncogene-a (GRO-a) }\end{array}$ & Unknown significance in breast & Unknown & \\
\hline $\begin{array}{l}\text { Monokine induced } \\
\text { gamma interferon (MIG) }\end{array}$ & $\begin{array}{l}\text { Promotes glucose metabolic } \\
\text { reprogramming and tumour growth }\end{array}$ & Pro & [24] \\
\hline
\end{tabular}




\begin{tabular}{|c|c|c|c|}
\hline Analyte & Reported activity in breast cancer & $\begin{array}{l}\text { Pro- or anti- } \\
\text { tumorigenic }\end{array}$ & Reference \\
\hline $\begin{array}{l}\text { Macrophage } \\
\text { inflammatory protein } \\
-1 a(\text { MIP-1a) }\end{array}$ & Unknown significance in breast & Unknown & \\
\hline $\begin{array}{l}\text { Macrophage } \\
\text { inflammatory protein } \\
-1 \beta \text { (MIP-1 } \beta)\end{array}$ & Unknown significance in breast & Unknown & \\
\hline $\begin{array}{l}\text { Stromal cell-derived factor } \\
1 \text { (SDF-1) }\end{array}$ & $\begin{array}{l}\text { Mediates metastasis and trafficking of } \\
\text { breast cancer cells }\end{array}$ & Pro & [25] \\
\hline $\begin{array}{l}\text { Vascular endothelial } \\
\text { growth factor (VEGF) }\end{array}$ & $\begin{array}{l}\text { Promotes tumour growth and } \\
\text { tumourigenesis }\end{array}$ & Pro & [4] \\
\hline $\begin{array}{l}\text { Granulocyte colony- } \\
\text { stimulating factor (G-CSF) }\end{array}$ & Enhances EMT, migration, and invasion & Pro & [8] \\
\hline $\begin{array}{l}\text { Epidermal growth factor } \\
\text { (EGF) }\end{array}$ & Promotes tumour cell growth & Pro & [4] \\
\hline $\begin{array}{l}\text { Fibroblast growth factor } \\
\text { (FGF) }\end{array}$ & $\begin{array}{l}\text { Promotes tumour growth, metastasis and } \\
\text { resistance to therapy }\end{array}$ & Pro & [26] \\
\hline ADAMTS13 & Unknown significance in breast & Unknown & \\
\hline $\begin{array}{l}\text { Growth/differentiation } \\
\text { factor-15 (GDF-15) }\end{array}$ & Increases tumour spheroid formation & Pro & [27] \\
\hline Lipocalin-2/NGAL & Promotes breast cancer metastasis & Pro & [28] \\
\hline Myeloperoxidase (MPO) & $\begin{array}{l}\text { Expressed by neutrophils, associated with } \\
\text { good prognosis }\end{array}$ & Anti & [29] \\
\hline Myoglobin & $\begin{array}{l}\text { Protects cells due to increased ROS and } \\
\text { NO scavenging }\end{array}$ & Pro & [30] \\
\hline $\begin{array}{l}\text { Soluble intercellular cell } \\
\text { adhesion molecule-1 } \\
\text { (sICAM-1) }\end{array}$ & $\begin{array}{l}\text { Associated with metastatic breast cancers, } \\
\text { but significance unknown }\end{array}$ & Unknown & [31] \\
\hline $\begin{array}{l}\text { Soluble vascular cell } \\
\text { adhesion molecule-1 } \\
\text { (sVCAM-1) }\end{array}$ & $\begin{array}{l}\text { Elevated in breast cancers, but significance } \\
\text { unknown }\end{array}$ & Unknown & [31] \\
\hline P-selectin & $\begin{array}{l}\text { Elevated in breast cancer patients causing } \\
\text { platelet aggregation }\end{array}$ & Pro & [32] \\
\hline
\end{tabular}

Table 2. Dunnett's test comparison of acidic medium treatments to untreated control 


\begin{tabular}{|llllll|}
\hline & $\begin{array}{l}\text { Mean } \\
\mathbf{1}\end{array}$ & $\begin{array}{l}\text { Mean } \\
\mathbf{2}\end{array}$ & $\begin{array}{l}\text { Mean } \\
\text { difference }\end{array}$ & $\begin{array}{l}\text { 95\% Cl of } \\
\text { difference }\end{array}$ & $\begin{array}{l}\text { Adjusted p- } \\
\text { value }\end{array}$ \\
\hline $\begin{array}{l}\text { Untreated vs. pH 6.5 15 } \\
\text { min }\end{array}$ & 294.0 & 97.53 & 196.5 & 141.4 to 251.6 & $<0.0001$ \\
\hline Untreated vs. pH 6.5 1hr & 294.0 & 675.3 & -381.3 & -436.4 to -326.2 & $<0.0001$ \\
\hline $\begin{array}{l}\text { Untreated vs. } \mathbf{p H} 3.215 \\
\text { min }\end{array}$ & 294.0 & 71.67 & 222.4 & 167.3 to 277.5 & $<0.0001$ \\
\hline Untreated vs. $\mathbf{p H} 3.2$ 1hr & 294.0 & 61.39 & 232.6 & 177.5 to 587.7 & $<0.0001$ \\
\hline
\end{tabular}

Table 3. 1-way ANOVA and Dunnett's test per analyte

\begin{tabular}{|c|c|c|c|c|c|}
\hline \multirow[t]{2}{*}{ Analyte } & \multirow{2}{*}{$\begin{array}{l}\text { 1-way } \\
\text { ANOVA p- } \\
\text { value }\end{array}$} & \multicolumn{4}{|c|}{ Dunnett's adjusted p-value } \\
\hline & & $\begin{array}{l}\text { Untreated vs. pH } \\
6.515 \mathrm{~min}\end{array}$ & $\begin{array}{l}\text { Untreated vs. } \\
\text { pH } 6.51 \mathrm{hr}\end{array}$ & $\begin{array}{l}\text { Untreated vs. pH } \\
3.215 \mathrm{~min}\end{array}$ & $\begin{array}{l}\text { Untreated vs. } \\
\mathrm{pH} 3.21 \mathrm{hr}\end{array}$ \\
\hline VEGF & $0.0045^{\star \star}$ & $0.0042^{\star \star}$ & $0.0094^{\star \star}$ & $0.0340^{*}$ & $0.0022^{\star \star}$ \\
\hline G-CSF & 0.0987 & 0.9999 & 0.9935 & 0.9553 & 0.0958 \\
\hline EGF & $0.0260 *$ & 0.2839 & $0.0325^{\star}$ & 0.3711 & 0.6997 \\
\hline FGF & $0.0443^{\star}$ & 0.1644 & 0.1671 & 0.0891 & $0.0163^{\star}$ \\
\hline IP-10 & 0.1512 & 0.2519 & 0.9994 & 0.3805 & 0.8791 \\
\hline GDF-15 & $<0.0001^{\star \star \star \star}$ & $0.0015^{\star \star}$ & $<0.0001^{\star \star \star \star}$ & $0.0007 * \star \star$ & $0.0008^{\star * \star}$ \\
\hline Myoglobin & $<0.0001^{\star \star \star \star}$ & $<0.0001^{\star \star \star \star}$ & $<0.0001^{\star \star \star \star \star *}$ & $<0.0001^{\star \star \star \star \star}$ & $<0.0001^{\star \star \star \star \star}$ \\
\hline
\end{tabular}

${ }^{*} p \leq 0.05 ;{ }^{* \star} p \leq 0.01 ; * * * p \leq 0.001 ; * \star * * p \leq 0.0001$

\section{Supplementary Files}

This is a list of supplementary files associated with this preprint. Click to download.

- SupplementarydatafileMCF.docx 